\title{
“THINK SUSTAINABLE, ACT LOCAL" - A STAKEHOLDER-FILTER-MODEL \\ FOR TRANSLATING SDGS INTO SUSTAINABILITY INITIATIVES WITH LOCAL \\ IMPACT
}

\author{
Steffen Raub \\ Ecole hôtelière de Lausanne \\ HES-SO // University of Applied Sciences Western Switzerland \\ Route de Cojonnex 18 \\ 1000 Lausanne 25. Switzerland \\ steffen.raub@ehl.ch \\ Carlos Martin-Rios* \\ Ecole hôtelière de Lausanne \\ HES-SO // University of Applied Sciences Western Switzerland \\ Route de Cojonnex 18 \\ 1000 Lausanne 25. Switzerland \\ carlos.martin-rios@ehl.ch
}

\section{INTERNATIONAL JOURNAL OF CONTEMPORARY HOSPITALITY MANAGEMENT}

Special issue call for papers: Sustainability and Corporate Social Responsibility in Hospitality

* Corresponding author and Tourism

Published in International Journal of Contemporary Hospitality

Management, 2019, Vol. 31 No. 6, pp. 2428-2447, which should be cited to refer to this work.

DOI : 10.1108/IJCHM-06-2018-0453 


\section{STRUCTURED ABSTRACT}

Purpose: The purpose of this paper is to develop and illustrate a comprehensive framework for how hospitality firms can overcome the broad vs. narrow dilemma in sustainable management. We develop a framework for how to break down the United Nations SDGs into actionable and context-specific subsets and select individual sustainability initiatives with maximum impact. Design/methodology/approach: Our framework is based on a comprehensive literature review of sustainable development, sustainable management in hospitality, and the issue-focused stakeholder perspective. Drawing on this research we develop a theoretical framework for the selection of impactful sustainability initiatives in the hospitality industry. In addition, the paper provides a broad range of concrete examples for how different stakeholders can act as barriers or catalysts for the implementation of sustainability initiatives.

Findings: The major contribution of this paper is twofold. First, it recognizes that the solutions to the great sustainability challenges ahead involve active participation of the hospitality industry in establishing partnerships with stakeholders. Secondly, it offers an ambitious roadmap for hospitality firms to identify local issues specific to sustainable management actions committed to advancing the social, environmental and economic dimensions of sustainability.

Practical implications: Our framework has considerable practical implications in that it is centered on helping hospitality firms select an appropriate set of SDGs for their local context and translate them into specific sustainability initiatives that address these goals. The "stakeholder-filter model" methodology is aligned with an approach that is already being used for the development of sustainability initiatives outside the scope of the hospitality industry. As a result, the framework should have substantial practical value for the hospitality industry. 


\section{Introduction}

In an unprecedented act of consensus in human history in 2012 all 195 member countries of the United Nations committed to create a unified framework of 17 sustainable development goals (SDGs) and their 169 targets. These SDGs would be integrated into the follow-up to the original eight Millennium Development Goals (MDGs) that helped promote global awareness, political accountability, improved metrics, social feedback, and public pressures (Griggs et al., 2013). That agreement brought important consequences for businesses; particularly for the hospitality sector.

The hospitality industry is a major driver of economic development and has a major impact on several facets of the SDGs. Research suggests that a strong commitment to SDGs by adopting sustainable practices has the potential to be beneficial for the hotel and tourism industry (Bricker et al., 2012) as well as for the countries in which hospitality firms operate (Jones et al., 2016). Through their direct operations, hotel companies can generate employment and economic growth in addition to profits in the countries they operate. And through partnerships with government and civil society, they can enhance their contribution to the natural environment, climate change, and social capital.

Unfortunately, there is a significant gap between the very comprehensive framework of the SDGs and the often relatively narrow range of sustainability initiatives that are being implemented by hotels (Bruns-Smith et al., 2015). This is due to a paradoxical situation. On the one hand, the 17 SDGs are deliberately broad and comprehensive. On the other hand, individual hospitality firms face specific local cultures, legal frameworks, workforce characteristics, customer characteristics and economic challenges that may serve as unique incentives or 
obstacles for the implementation of sustainability initiatives. As a result, when it comes to sustainability, hotels are more likely to opt for a narrow strategy that is limited to the integration of sustainable operational activities in their current practices than adopting a broad strategyaligned with the triple bottom-line that seeks to create economic, ecological and social value in partnership with stakeholders (Akenji and Bengtsson, 2014). The consequence of this paradox, especially for an industry like hospitality that has global reach and faces a large variety of specific local issues, is that "one size clearly does not fit all". Therefore, the 17 SDGs require regional and local "differentiation", a necessity that is also explicitly acknowledged by its authors (United Nations, 2017).

Drawing on sustainable tourism and stakeholder theory (Byrd et al., 2009), the purpose of this paper is to develop a comprehensive framework for how hospitality firms can overcome the broad vs. narrow dilemma by breaking down the 17 SDGs into actionable and context-specific subsets and by selecting individual sustainability initiatives with maximum impact within the chosen set of SDGs. Our macro-framework offers propositions along the following three dimensions:

- Sustainable development in hospitality: in line with existing research (e.g. Deery et al., 2012), it is extremely important to understand the social impacts of sustainable hotels on local communities to increase the likelihood of positive sustainable management actions.

- Issue-focused stakeholder involvement: synergies between SDGs and local sustainable practices need to address the opportunities and barriers pertinent to stakeholder engagement (Waligo et al., 2013). 
- Implementation of SDGs: successful implementation of local business sustainability management practices requires that they be aligned with economic advantages for the businesses themselves.

This study is conducted through a comprehensive literature review based on three dimensions: sustainability, sustainable management and stakeholder perspective of hospitality research. This paper focuses on the development of a theoretical framework for the selection of impactful sustainability initiatives in the hospitality industry. The framework development will proceed in two steps. First, we will develop a macro framework of environmental variables that allows for the differentiation of SDGs to the conditions of hospitality firms in a specific local context. Second, we will describe a methodology for a "stakeholder-filter-model" that allows hotels to identify high-impact activities that address the most important SDGs in their specific local context.

The major contribution of this paper is twofold. First, it recognizes that the solutions to the great sustainability challenges ahead related to SDGs involve active participation of the hospitality and tourism industry in establishing collaborative partnerships and sharing expertise with diverse stakeholders. Stakeholder engagement is crucial to the success of sustainable development in hotels. The sustainable response patterns of local hotels are complex and require communication and coordination with internal and external stakeholders. Secondly, it offers a hands-on "stakeholder-filter model" methodology for the hotel industry to identify and develop SDG-related initiatives specific to regional and local hotels committed to advancing the social, environmental and economic dimensions of sustainability. 


\section{Translating SDGs into sustainable management: A framework}

The United Nations has formally adopted a set of 17 Sustainable Development Goals (SDGs), as part of the new global 'Agenda 2030 for Sustainable Development'. "An agenda for people, to end poverty in all its forms - an agenda for the planet, our common home," as declared Secretary-General Ban Ki-moon (United Nations, 2015). Agenda 2030 builds on the eight Millennium Development Goals (MDGs), approved in 2000 to tackle extreme poverty in developing countries (Table 1).

-------Insert Table 1 about here-------

As well as being more comprehensive than the MDGs, the SDGs aim at getting concerted efforts of governments, society, foundations, aid organizations, NGOs and the business sector. The Sustainable Development Goals form a network of targets (Le Blanc, 2015), in which links among SDGs exist through targets that refer to multiple goals and key players with various levels of involvement. Griggs and colleagues argue that the SDG framework "manages tradeoffs and maximizes synergies between targets, and can be implemented from international to city scales" (2013, pp. 307). As shown in Figure 1, some of these goals cover a much broader range of issues (humanitarian, political, and legal perspectives), whereas other SDGs have associated targets that explicitly refer to the economic playing field.

-------Insert Figure 1 about here-------

The network of targets recognizes that the solutions to the great sustainability challenges ahead involve active participation of the private sector-hospitality industry, in establishing 
partnerships between policy, industry, tourism and civil society. Yet, questions remain as to how hospitality firms can overcome the task of implementing SDGs by breaking them down into actionable and context-specific subsets and by selecting individual sustainability initiatives with maximum impact within the chosen set of goals. At stake is the very notion of sustainable development and how hotels integrate sustainable development in their operations by means of sustainable management practices.

\section{Sustainable development and sustainable management in hospitality}

According to the United Nations, sustainable development is "the development that meets the needs of the present without compromising the ability of future generations to meet their own needs" (WCED, 1987). Sustainable development rests on the well-known triple bottom-line principles - seeking to create economic, ecological and social value simultaneously. Existing research suggests that the hospitality and tourism industries have substantial social, economic and environmental impacts on communities (e.g. Deery et al., 2012). The conclusion is that it will be of upmost importance to engage important industry players more deeply and extensively in the pursuit of SDGs in order to increase the likelihood of positive contributions from these industries to sustainable development. The relationship between hospitality and sustainable development has been addressed by various streams of research, such as eco-hospitality, green practices and sustainable hospitality. In terms of extant literature, authors have addressed the impact of sustainable development on outcomes as diverse as customer satisfaction (Prud'homme and Raymond, 2013), regional development (Bunakov et al., 2015), or food waste (Martin-Rios et al., 2018).

However, research on sustainable management in hospitality also suggests that for too many firms in the industry the core motivation and main goals with regard to sustainable hospitality are still focused primarily on reaping short-term economic benefits (Melissen, 2013; Myung et 
al., 2012). This focus on cost-saving through sustainability initiatives is reflected in the World Economic Forum's recommendations to adopt more efficient technologies per hotel room, so that "reductions in carbon emissions will primarily be driven by the use of existing mature technologies in lighting, heating and cooling that can significantly improve hotel energy efficiency" (WEF, 2009, p. 7). This observation stands in contrast to the fact that sustainable management, in essence, should involve the application of sustainable business practices to the three bottom lines - people, planet and profit - rather than being limited to the economic aspect alone. Indeed, a more comprehensive approach to sustainable management in hospitality would require paying attention to the adoption of technological, behavioral and policy innovations that contribute to promoting more sustainable patterns of consumption and changes in hotel guests' behaviors (Hall, 2013).

This situation leaves hospitality firms in a dilemma. On the one hand, the enlarged ambition and scope of the SDGs can only be met when hospitality firms explicitly integrate SDGs into their strategic plans and initiate, promote and sustain organizational practices and operational hotel activities that are aligned with sustainable development principles as outlined in the SDGs. On the other hand, a core challenge of sustainable management in hospitality remains the alignment of specific environmental and social issues with economic approaches (Figge et al., 2002). In practice, this requires sustainable management in hospitality to be aligned with certain advantages for the businesses themselves (Kim et al., 2017). The social and environmental issues will not be embedded in corporate strategies and sustainable practices in hotels will not be implemented, unless economic and business factors, including financial strength, managerial attitudes, new leadership approaches and new organizational methods, are taken into account.

This paper suggests that the solution to overcoming this dilemma lies in a renewed focus on stakeholders. A narrow internal focus on operational benefits related to sustainability initiatives will be a double impediment for hospitality firms. On the one hand it limits the scope of 
practical sustainability initiatives that will be selected. On the other hand it isolates the firm from its surrounding stakeholders, thereby effectively forfeiting the possibility to find synergies in implementing sustainability actions with a broader scope. Conversely, a more rigorous examination of stakeholder preferences, and closer collaboration with stakeholders will allow hospitality firms to cast a wider net and to tap into a broader reservoir of resources and partnerships.

\section{Stakeholder classification and stakeholder relationship with SDGs}

In general terms, stakeholders are groups or individuals that materially affect or are affected by a firm's activities (Freeman, 1984). By extension, stakeholder management represents a new managerial model that incorporates external parties into the traditional internal company activity (Clarkson, 1995). The purpose of a stakeholder management approach is to ensure that companies strategically take into consideration the interests and requirements of all individual and group constituencies that may be affected by or have an effect on any project, initiative, intervention, or effort the company engages in.

Stakeholders have been categorized as internal or external stakeholders (Freeman, 1984) or as primary and secondary stakeholders (Clarkson, 1995). The hospitality literature has developed a finer typology (for a recent review, see Waligo et al., 2013) including guests/tourists, local community, special interest groups, government and other authorities (Currie et al., 2009; Freeman, 1984; Waligo et al., 2013). A broader mapping of hotel's stakeholders related to sustainability initiatives may also include professional associations, accreditation agencies, or educational institutions (see Figure 2).

\section{-------Insert Figure 2 about here-------}

The stakeholder literature typically takes the viewpoint that corporate responses to environmental demands are associated with strong stakeholder pressure (Scherer et al., 2013). 
In a similar vein, many academics writing on sustainability have used the stakeholder management concept to investigate how firms react to environmental pressures from various constituencies. One important concern has been to identify who are the stakeholder groups that demand sustainability friendly services and practices. In the hospitality context, studies have shown that hotel firms' commitment to sustainability is influenced by external business factors, particularly, stakeholder pressure and environmental regulations (Prud'homme and Raymond, 2013).

Rather than framing stakeholders exclusively as sources of environmental pressure, one could also turn the perspective around and see them as potential allies and partners on specific issues of interest to the firm. This distinction is reflected in the broad/narrow (unidimensional vs. multidimensional) perspective from which to examine stakeholder salience and to handle their different demands (Mitchell et al., 1997). So far, hospitality research has tended to look at sustainability and stakeholders from a broad, macro perspective (e.g. Teng et al., 2015), i.e. hospitality firms react to stakeholder demands in a generalized, non-coordinated fashion, without evaluating possible contradictions and overlaps in stakeholder demands. This traditional broad approach to stakeholder management provides only a general framework for specifying and interpreting the divergent views of groups (Mitchell et al., 1997), and thus offers little guidance for selecting appropriate sustainable initiatives and maximizing joint outcomes.

Conversely, there has been considerably less focus on the reasons why certain stakeholder groups advocate or oppose different sustainable standards and practices. This paper argues that such an issue-focused stakeholder management represents a widely accepted approach to solving the problems associated with a lack of understanding and few shared common goals between the many stakeholders often involved in sustainable development (Waddock, 2008). The degree to which managers give priority to multiple, oftentimes, competing stakeholder claims results in different levels of involvement and collaboration. The notion of stakeholder 
salience, defined as the power, legitimacy, and urgency attributed to stakeholders, help explain how hotels prioritize the demands placed on them by various stakeholders and establish critical stakeholder relationships to address sustainable practices. As a matter of fact, existing research has shown the benefits of developing proactive relationships between the company and its respective stakeholders to promote sustainable initiatives (Buysse and Verbeke, 2003; Currie et al., 2009; Murillo-Luna et al., 2008; Wagner et al., 2012).

Instead of focusing on isolated, broad reactions to stakeholder groups, an issue-focused stakeholder management begins in a bottom-up process, starting with specific sustainability issues and linking these to specific stakeholders for whom these issues are relevant. Firms then assess the extent to which each different stakeholder may provide external resources, which serve as catalysts or barriers to effective implementation of sustainable initiatives (Kim et al., 2017). Such an approach facilitates the uncovering of synergies between local hospitality firms and specific SDGs actions required to address the needs of stakeholders. It allows for the identification of actionable ways of dealing with stakeholders perceptions of the opportunities and obstacles related to actual implementation of SDGs.

The next section shows what can be understood by a stakeholder-model of sustainable management of SDGs and how it is distinguished from other kinds of environmental and socially responsible activity of hotels. From the stakeholder theory of sustainable management, the two main dimensions, catalysts and barriers to adoption of SDGs in local contexts, are discussed in more detail. Moreover, the model offers a roadmap to identify, ponder and put into action SDG goals specific to local hotels committed to advancing the social, environmental and economic dimensions of sustainability. 


\section{A proposed model of sustainable management and SDGs}

Drawing on issue-focused stakeholder theory, we develop the following stakeholder-filtermodel of SDG implementation in hospitality. Adapting SDGs to the local context in the realm of hospitality and tourism requires a contingent approach to specific local communities in managing and measuring corporate social, environmental, and economic impacts. The framework for SDGs discussed here and described in Figure 3 considers a multi-step process that allows for the adaptation of sustainable management practices to the individual firm. The model takes into account potential barriers and catalysts as well as a proactive relationship with stakeholders to obtain external and internal leverage.

--- Insert Figure 3 about here ---

\section{Details of the model}

Our framework suggests that hospitality companies tackle the broad vs. narrow dilemma in a 7-step process. This process is represented in Figure 3. The hourglass shape of the model indicates a dual process of narrowing and broadening. Beginning from the broadest level of the full spectrum of the 17 SDGs, the first challenge is to advance through a funnel of stakeholder forces and narrow them down to a small number of goals with reasonable chances of implementation. Once the narrowest point of the hourglass has been reached, the subsequent challenge consists of gathering momentum and building support around this limited set of objectives with the purpose of generating maximum impact. 
Practical evidence suggests that such a "narrowing" process takes place quite frequently and often involves several players. As a case in point, the 17 SDGs were initially integrated into the sustainability agenda of the World Travel and Tourism Council (World Travel and Tourism Council, 2018). From the WT\&T's action agenda, a narrowed-down choice of SDGs found their way into the industry, among other things by the endorsement of major industry players such as the Marriott Corporation (Marriott, 2018a). After this initial endorsement, Marriott refined their own choice of sustainability goals. Under the heading "Serve360", Marriott now presents their own sustainability agenda that focuses on a more restrictive set of objectives, but is closely aligned with the SDG logic and even uses the official SDG logos to highly main areas of impact of every corporate sustainability initiative. In a similar vein, Pepsico has selected a variety of specific sustainability objectives for their 2025 agenda (Pepsico, 2015). Presented under the headings of products, planet and people, each of the chosen objectives is clearly aligned with at least one of the SDGs.

In the following sections we will describe every step in detail and illustrate it with concrete examples.

Step 1: Assess relevance of hospitality industry contributions to the 17 SDGs

The 17 SDGs are intended to serve as guidelines for country-level sustainable development policies and programs. Even though the private sector is invited to contribute to their realization and multi-stakeholder partnerships are explicitly recognized as a major driver for their implementation, the 17 SDGs differ in the extent to which they allow for private sector contributions. 
For instance, as shown in Figure 1, whereas the goals of "end poverty" (\#1), "end hunger" (\#2) and "peaceful and inclusive societies" (\#16) seem to call primarily for country-level programs and legislative efforts, other goals like "sustainable economic growth" (\#8), "sustainable consumption and production" (\#12) or "combat climate change" (\#13) provide ample opportunities for private sector initiatives and multi-stakeholder efforts.

Therefore, a first preliminary step towards narrowing the scope of the 17 SDGs consists of assessing the possibility of making relevant contributions at the hospitality industry level. However, this assessment depends on the regional and local context. For instance, basic professional training for entry-level hospitality jobs can be a very meaningful contribution towards the objective of "quality education" (\#4) in a developing country context. For example, the Ecole Paul Dubrule is a vocational hospitality school sponsored by the Accor Group (France) and supported by the Ecole hôtelière de Lausanne (Switzerland) and the Association of Southeast Asian Social Enterprises for Training in Hospitality \& Catering (ASSET-H\&C). Such partnership takes the form of financial, academic and managerial support and interventions of experts in Cambodia. In an industrialized country, the relevance of this SDG and the possibility for hospitality firms to make a meaningful contribution with a similar initiative may be substantially lower.

\section{Step 2: Identify all relevant stakeholders}

In this step, the objective is to compile a list of stakeholders who can act as supporting or opposing forces for sustainability initiatives within the scope of the pre-selected SDGs. A generic list of external and internal stakeholders (Pérez and del Bosque, 2014; Waligo et al., 2013) may serve as a starting point. External stakeholders are likely to include guests, suppliers, local industry bodies, professional associations, local community, special interest groups, 
analysts and media, as well as governmental and educational institutions. Internal stakeholders include employees, shareholders and other corporate players in the case of multinational chains.

The selection of relevant stakeholders is again highly dependent on the local context. This is true for external as well as internal stakeholders. For instance, political systems may vary from one country to another, and the presence of NGOs and other special interest groups is highly context-dependent. Conversely, when it comes to internal stakeholders, the situation of an independent hotel may be radically different from that of a property of a multinational chain that has to comply with the priorities of an internal sustainability unit. Take the example of the four strategic priorities of AccorHotel's Planet 21 Program: employees, customers, partners and local communities (Accor, 2018). Within this strategic framework, Accor puts particular emphasis on the key issues of sustainable food and sustainable buildings.

Employees and managers are a central stakeholder group to influence SDG initiatives. They may be pivotal beyond just being mere "receivers" or passive adopters of a SDG action that is to be executed. They operationalize, comply with, disrupt or change sustainable intentions (Kramar, 2014; Ramus, 2002). They can advocate an internal culture for SDGs (del Rosario and Rene, 2017), or act as points of resistance (Fraj et al., 2015). In response, a stakeholderfilter-model of SDGs implementation cannot be limited to a focus on external stakeholders, but must put comparable emphasis on how managers and employees are enabled to engage in making SDG-related decisions and practices happen.

\section{Step 3: List catalysts and obstacles of each stakeholder for each SDG}

Based on a list of relevant stakeholders, this step is potentially the most difficult and time consuming. The challenge here is to gain a comprehensive overview of how each stakeholder 
may impact the local implementation of sustainability initiatives related to specific SDGs. We suggest that stakeholders can serve as catalysts or obstacles for the implementation.

When stakeholders act as catalysts, they can make one or several of the following contributions: a) highlighting the importance of an SDG in the local context and creating awareness, b) providing opportunities for communication activities around the chosen SDG, or c) providing support for the implementation of activities in the form of financial resources, human resources or knowledge and expertise. When they act as obstacles they may a) emit legal barriers, b) undermine the credibility of initiatives through communication or c) render the implementation of sustainability activities economically more challenging. Since this step is of the greatest practical relevance, and probably also of the highest degree of difficulty, we will dedicate the entire next section of this paper to numerous practical examples of how a broad range of stakeholder groups can be considered in the context of our framework.

\section{Step 4: Determine the Implementation Probability Index (IPI) for each SDG}

Based on the painstaking work carried out in the previous stage, the following step 4 consists of applying a metric to determine the combined impact of different stakeholders for each SDG. Due to the fact that stakeholders can exert both supportive and negative forces on individual sustainability initiatives, the metric has to include positive and negative values so as to allow for possible compensation between the forces. The chosen scale is arbitrary. It may be a onestar to three-star or 0-100 point scale. The essence is that the strength of each shareholder impact can be represented with sufficient precision and in the form of a scale that has interval properties.

Summing up supportive and negative forces leads to a combined index for each SDG which we name the "Implementation Probability Index" (IPI). A negative index or one that is around zero 
signals limited potential for sustainability initiatives related to the focal SDG. The more positive the IPI is, the more implementation efforts will fall on fertile ground from a stakeholder perspective.

\section{Step 5: Shortlist and select High Impact SDGs}

Step 5 consists of establishing a final list of one or several SDGs on which the sustainability efforts of a focal hotel property should be focused. A certain cut-off value may be defined below which SDGs are excluded. The number of chosen SDGs depends obviously not only on the IPIs they obtained but also on the available time and resources at the level of the property.

Step 6: Multiply organizational initiatives to support selected SDGs and empower broad-based internal participation

The implementation of sustainability efforts have to face the same challenges as any large-scale organizational change effort. These may range from lack of perceived urgency, internal political resistance, to lack of resources and employee buy-in. As a result, once one or several promising SDGs have been identified, it is critical to support their implementation with an appropriate change management approach (Kotter, 1996). This includes a clear internal vision and strategy, a "guiding coalition" of influential managers who lend support to the initiative and "walk the talk" (Raub, 2017) and, last but not least, an organizational setup that allows for broad-based participation of employees in the initiative. The objective of these steps is to create a sufficient momentum for the initiative so that its implementation will not be threatened by the burden of daily business.

The implementation of SDG initiatives needs to go hand in hand with actual sustainable management practices. In hotels, management time and resources are limited, so managers need 
to widen their attention and work collaboratively to generate the achievement of sustainable management solutions. At the hotel property level, this includes a range of activities, including setting the agenda for SDG implementation, keeping track of managerial decisions related to SDGs, distributing decision-making and accountability for collective duties, forecasting future plans from current issues and assessing progress and outputs. Another important operational aspect concerns the development of sustainability-related skills among the property's employees.

Step 7: Network, collaborate with and leverage internal and external stakeholders to maximize impact

Finally, when internal momentum has been created, the success probability of sustainability initiatives can also be increased by leveraging the support of the organization's network of external relationships. The greatest opportunities to implement SDGs will come from specific initiatives where the business significantly interacts with-and thus can have the greatest impact on-stakeholders. These are areas where hotels not only can gain a deeper understanding of the mutual challenges but also in which the highest potential for mutual benefit exists.

\section{Assessing stakeholder impact on specific SDGs - Some practical examples}

In this final section we will put a magnifying glass on the essential Step 3 of the model. For a range of different stakeholder groups we will share practical examples of how they could influence the SDG selection process. 


\section{Guests/Tourists}

Research has suggested that even though many guests describe themselves as interested in environmental issues, only a much smaller proportion is willing to pay for eco-friendly products and services (Kyung et al., 2012). However, individual differences in terms of environmental awareness are positively related to the willingness to spend more on sustainable products (Kyung et al., 2012). Similarly, individuals with a greater orientation towards nature expressed more favorable attitudes towards environmentally responsible business practices in hospitality.

While a limited willingness to share in the cost of sustainability initiatives is generally seen as a barrier to implementation, individual guest preferences and positive attitudes towards sustainability can also be viewed as a sustaining force. A number of hospitality firms have been successful in partnering with guests by tapping into their environmental orientation. For instance, at Marriott the "Make a Green Choice" option allows guests to forego full housekeeping in exchange for F\&B vouchers or loyalty points (Marriott, 2018b). A reduced consumption of chemicals and cleaning products is a desirable side-effect of this initiative. At AccorHotels, the "Plant for the Planet" initiative allows guests to reuse their towels with the resulting savings being invested in planting trees around the world. North Korean tourism organizations even co-opt tourists to plant rice on organized "labor tours" that include planting and harvesting activities in rural sites (Worley, 2017).

\section{Shareholders}

Shareholders are an often underestimated force when it comes to assessing stakeholder impact on sustainability initiatives. Financial short-termism is an obvious barrier to the implementation 
of sustainability programs (Erikson, 2012). However, shareholders can also act as supportive forces for sustainability. Rather than exercising influence merely via the purchase or sale of shares, shareholders have the possibility of submitting shareholder proposals, also known as shareholder resolutions, to encourage management action on particular issues. Even though these are non-binding and often do not even receive a majority vote from shareholders, a sizable level of support does often prompt managerial action (Grewal et al., 2016). Over the past decade, environmental and social shareholder resolutions have become the single most important category of proposals (Guardian, 2013), reaching almost 50\% of all proposals. Investor networks have been successful in convincing companies to engage in a range of sustainability initiatives, ranging from sustainable sourcing of problematic products like palm oil to better environmental practices in the extraction of fossil fuels.

\section{Industry associations and special interest groups}

A broad range of industry associations and special interest groups can serve mostly as catalysts for sustainability actions in hotels. For instance, the Swiss Hotel Association (Hotellieresuisse, 2018) partners with hotel schools in Switzerland to deliver vocational training in sustainable management for professional and executive staff of hotel firms in Switzerland. Smaller, regional hotel associations, like the Greater Miami and the Beaches Hotel Association (GMBHA), have also established Sustainable Hospitality Councils to advance the awareness and adoption of sustainable practices by providing guidance, expertise and resources to Association members. GMBHA, member of the American Hotel and Lodging Association, has

partnered with the U.S. Environmental Protection Agency's (EPA's) WaterSense Hotel Challenge Platform to launch different initiatives for local hoteliers in the Greater Miami area. 
Initiatives aim to reduce water consumption, water-wasting products or processes, and track water-saving progress, resulting by saving water and reducing hotel's utility bill costs.

Another special interest group which can act as catalyst is constituted by accreditation agencies. For example, the Global Sustainable Tourism Council (GSTC), which is "an independent and neutral organization, legally registered in the USA as a 501(c)3 non-profit organization that represents a diverse and global membership, including UN agencies, NGO's, national and provincial governments, leading travel companies, hotels, tour operators, individuals and communities - all striving to achieve best practices in sustainable tourism." GSTC certifies that hotels/accommodations, tour operators, and destinations have sustainable policies and practices in place (GSTC, 2018).

\section{National and local government agencies}

National and local governments have substantial leverage over catalysts and barriers to sustainability initiatives in the hospitality industry. A case in point is the recent decision by the Philippine president Rodrigo Duerte to shut down Boracay island which accounted for over a billion US\$ tourism revenue (Guardian, 2018). This political decision represents both a catalyst - by attracting attention to the importance of marine life and sustainability activities focused on improving water quality - and an obstacle - due to the lost revenue it caused. National policies can provide support for sustainability initiatives, such as the agro-ecology project in France (Ministère de l'Agriculture, de l'Agroalimentaire et de la Forêt, 2016) or prompt them in coercive ways, such as the British initiative to ban the sale of single use products, including plastic straws (Reuters, 2018). 
Increasingly, however, local governments focus on becoming catalysts for sustainable development by providing resources to support effective sustainable management practices in hotels. For example, the city of Melbourne offers free programs to help hotels optimize their environmental footprint. Also, the City government sponsors the Melbourne Renewable Energy Project (MREP) that gathers a group of local governments, cultural institutions, universities and corporations to purchase renewable energy. Through the Sustainable Melbourne Fund, it offers loans for businesses that intend to implement sustainable management initiatives in water, energy, waste efficiency and new, clean technologies (City of Melbourne, 2018).

\section{Corporate management}

Last but not least, from the viewpoint of a local property in a hotel chain, corporate sustainability programs can place heavy emphasis on certain objectives, potentially to the exclusion of others. Most international hotel chains have corporate staffs that set a global sustainability agenda which narrows down the list of possible sustainability objectives. For instance, under the heading "Planet 21" ACCOR not only engages in co-innovation with partners and collaboration with local communities but has also defined tow strategic axes for their global sustainability initiatives: healthy and sustainable food and ecological buildings. These two strategic priorities provide strong incentives for local properties to engage in initiatives that are aligned with the corporate priorities.

Marriott has defined Sustainability \& Social Impact Goals for 2025. The label "Serve360" breaks sustainability initiatives down into the four areas of nurturing, empowering, sustaining, and welcoming. Each of these focal topics includes tangible and measurable objectives, and the initiatives within each area are specifically aligned with a selection of SDGs. Managers at the 
local property need to take these corporate imperatives into account when trying to determine on which specific sustainability objective they want to work.

\section{Conclusion}

The hotel industry is a major partner that will contribute to the ultimate success of the SDGs. A thorough review of the literature on sustainability and sustainable management in the hospitality industry leads to the conclusion that there is currently a misalignment between the ambitious agenda of the 17 SDGs and the actual sustainability practices in many if not most hospitality firms. Sustainability initiatives in the hospitality sector suffer from three major limitations: a narrow focus on cost-saving, a predominantly internal organizational focus, and an insufficient consideration of stakeholders as potential partners and catalysts in the implementation of specific sustainability initiatives.

Our paper is based on the intuition that these limitations may at least partly be due to the lack of a comprehensive and hands-on framework that can bridge the broad/narrow divide that we have highlighted. Drawing on sustainable development and issue-focused stakeholder theory, our paper suggests a practical 7-step approach for filtering SDGs and translating them into practical, locally focused and impactful sustainability initiatives. We hope that we have made a first step towards solving this dilemma for the hospitality sector. This is one of the first studies assessing the relevance of sustainable development and management research related to hospitality by considering the adaptation of SDGs to local context at three levels: sustainable development, stakeholder involvement and economic feasibility. As such this paper should be of interest to researchers and practitioners concerned with both the hospitality industry and corporate sustainability strategies and actions. Hopefully, this framework will quickly diffuse 
in the industry and will lead to greater impact, fort the good of hospitality firms as well as the planet as a whole. 


\section{REFERENCES}

AccorHotels (2018), "Planet 21", available at: https://www.accorhotels.com/gb/sustainabledevelopment/index.shtml (accessed 31 May 2018).

Akenji, L. and Bengtsson, M. (2014), "Making sustainable consumption and production the core of sustainable development goals", Sustainability, Vol. 6, No. 2, pp. 513-529.

Bricker, K. S., Black, R., and Cottrell, S. (2012), Sustainable tourism and the millennium development goals. Jones \& Bartlett Publishers.

Bruns-Smith, A., Choy, V., Chon, H. and Verma, R. (2015), "Environmental sustainability in the hospitality industry: Best practices, guest participation, and customer satisfaction", Cornell Hospitality Report, Vol. 15. No. 3, pp. 6-16.

Bunakov, O. A., Zaitseva, N. A., Larionova, A. A., Chudnovskiy, A. D., Zhukova, M. A. and Zhukov, V. A. (2015), "Research on the evolution of management concepts of sustainable tourism and hospitality development in the regions", Journal of Sustainable Development, Vol. 8, No. 6, pp. 39-44.

Buysse, K. and Verbeke, A. (2003), "Proactive environmental strategies: A stakeholder management perspective", Strategic Management Journal, Vol. 24, No. 5, pp. 453470.

Byrd, E.T., Bosley, H.E. and Dronberger, M.G. (2009), “Comparisons of stakeholder perceptions of tourism impacts in rural eastern North Carolina", Tourism Management, Vol. 30, No. 5, pp. 693-703.

City of Melbourne (2018), "Sustainable business", available at:

http://www.melbourne.vic.gov.au/business/sustainable-business/Pages/sustainablebusiness.aspx (accessed 31 May 2018). 
Clarkson, M.E. (1995), “A stakeholder framework for analyzing and evaluating corporate social performance", Academy of Management Review, Vol. 20, No. 1, pp. 92-117.

Currie, R.R., Seaton, S. and Wesley, F. (2009), "Determining stakeholders for feasibility analysis", Annals of Tourism Research, Vol. 36, No. 1, pp. 41-63.

Deery, M., Jago, L. and Fredline, L. (2012), "Rethinking social impacts of tourism research: A new research agenda", Tourism Management, Vol. 33, No. 1, pp. 64-73.

del Rosario, R.S. and René, D.P. (2017), “Eco-innovation and organizational culture in the hotel industry”, International Journal of Hospitality Management, Vol. 65, pp. 71-80.

Erikson, J. (2012), “Overcoming barriers to a green economy”, SustainAbility, Monday 5 March 2012, available at: http://sustainability.com/our-work/insights/overcomingbarriers-to-a-green-economy/(accessed 31 May 2018).

Figge, F., Hahn, T., Schaltegger S. and Wagner, M. (2002), “The Sustainability Balanced Scorecard: Linking sustainability management to business strategy", Business Strategy and the Environment, Vol. 11, No. 5, pp. 269-284.

Fraj, E., Matute, J. and Melero, I., (2015), "Environmental strategies and organizational competitiveness in the hotel industry: The role of learning and innovation as determinants of environmental success", Tourism Management, Vol. 46, pp.30-42.

Freeman E. (1984). Stakeholder management. Pitman: Mansfield, MA.

Grewal, J., Serafeim, G. and Yoon, A.S. (2016), "Shareholder activism on sustainability issues”, working paper, No. 17-003, Harvard Business School, University of Harvard, available at: https://dash.harvard.edu/handle/1/27864360 (accessed 31 May 2018). 
Griggs, D., Stafford-Smith, M., Gaffney, O., Rockström, J., Öhman, M.C., Shyamsundar, P., Steffen, W., Glaser, G., Kanie, N. and Noble, I. (2013), "Sustainable development goals for people and planet”, Nature, Vol. 495, No. 7441, pp. 305-307.

GSTC (2018), "What is the GSTC?”, available at: https://www.gstcouncil.org/about/about-us (accessed 31 May 2018).

Guardian (2013), “The shareholders putting sustainability on the agenda”, available at: https://www.theguardian.com/sustainable-business/blog/shareholders-puttingsustainability-on-the-agenda (accessed 31 May 2018).

Guardian (2018), “'Cesspool': Philippines president closes billion-dollar holiday island over raw sewage", available at:

https://www.theguardian.com/world/2018/apr/05/philippines-boracay-holiday-islandsewage-closed-duterte (accessed 31 May 2018).

Hall, C.M. (2013), "Framing behavioural approaches to understanding and governing sustainable tourism consumption: Beyond neoliberalism, 'nudging' and 'green growth'?", Journal of Sustainable Tourism, Vol. 21, No. 7, pp. 1091-1109.

Hotelleriesuisse (2018), "Professional Education and Training”, available at: https://www.hotelleriesuisse.ch/en/pub/education/professional education and tra.htm (accessed 31 May 2018).

Jones, P., Hillier, D. and Comfort, D. (2016), "Sustainability in the hospitality industry: some personal reflections on corporate challenges and research agendas", International Journal of Contemporary Hospitality Management, Vol. 28, No. 1, pp. 36-67.

Kim, S. H., Lee, K. and Fairhurst, A. (2017), "The review of "green" research in hospitality, 2000-2014: Current trends and future research directions", International Journal of Contemporary Hospitality Management, Vol. 29, No. 1, pp. 226-247. 
Kotter, J. (1996). Leading change. Boston: Harvard Business School Press.

Kramar, R. (2014), "Beyond strategic human resource management: is sustainable human resource management the next approach?", The International Journal of Human Resource Management, Vol. 25, No. 8, pp. 1069-1089.

Kyung, H.K., Stein, L., Heo, C.Y. and Lee, S. (2012), “Consumers' willingness to pay for green initiatives of the hotel industry", International Journal of Hospitality Management, Vol. 31, No. 2, pp. 564-572.

Le Blanc, D. (2015). Towards integration at last? The sustainable development goals as a network of targets. Sustainable Development, 23(3), 176-187.

Marriott (2018a), “2025 Sustainability \& Social Impact Goals”, available at: http://serve360.marriott.com/wpcontent/uploads/2018/03/Serve 360 goals page tabloid Mar2018.pdf (accessed 31 May 2018).

Marriott (2018b), “Serve360”, available at: http://serve360.marriott.com/(accessed 31 May 2018).

Martin-Rios, C., Demen-Meier, C., Gössling, S. and Cornuz, C. (2018), "Waste management innovation in the food service industry", Waste Management

Melissen, F. (2013), “Sustainable hospitality: a meaningful notion?”, Journal of Sustainable Tourism, Vol. 21, No. 6, pp. 810-824.

Ministère de 1'Agriculture, de l'Agroalimentaire et de la Forêt (2016), “The Agroecology project in France", available at: http://agriculture.gouv.fr/sites/minagri/files/1604-aecaeenfrance-dep-gb-bd1.pdf(accessed 31 May 2018). 
Mitchell, R.K., Agle, B.R. and Wood, D.J. (1997), “Toward a theory of stakeholder identification and salience: Defining the principle of who and what really counts", Academy of Management Review, Vol. 22, No. 4, pp. 853-86.

Myung, E., McClaren, A. and Li, L., (2012), "Environmentally related research in scholarly hospitality journals: Current status and future opportunities”. International Journal of Hospitality Management, Vol. 31, No.4, pp.1264-1275.

Murillo-Luna, J.L., Garcés-Ayerbe, C. and Rivera-Torres, P. (2008), "Why do patterns of environmental response differ? A stakeholders' pressure approach”, Strategic Management Journal, Vol. 29, No. 11, pp. 1225-1240.

Pepsico (2015), “Performance with Purpose - Sustainability report 2015”, available at: https://www.pepsico.com/docs/album/sustainabilityreporting/pepsico_sustainability_report_2015_and_2025_agenda.pdf(accessed 31 May 2018).

Pérez, A. and del Bosque, I. R. (2014), "Sustainable development and stakeholders: A renew proposal for the implementation and measurement of sustainability in hospitality companies", Knowledge and Process Management, Vol. 21, No. 3, pp. 198-205.

Prud'homme, B. and Raymond, L. (2013), "Sustainable development practices in the hospitality industry: An empirical study of their impact on customer satisfaction and intentions", International Journal of Hospitality Management, Vol. 34, pp. 116-126.

Ramus, C.A. (2002), “Encouraging innovative environmental actions: what companies and managers must do", Journal of World Business, Vol. 37, No. 2, pp. 151-164,

Raub, S. (2017), "When employees walk the company talk: The importance of employee involvement in corporate philanthropy", Human Resource Management, Vol. 56, No. 5, pp. 837-850. 
Reuters (2018), "Britain to ban sale of plastic straws in bid to fight waste", available at: https://www.reuters.com/article/us-britain-chogm-plastic/britain-to-ban-sale-ofplastic-straws-in-bid-to-fight-waste-idUSKBN1HP338 (accessed 31 May 2018).

Scherer, A.G., Palazzo, G. and Seidl, D. (2013), "Managing legitimacy in complex and heterogeneous environments: Sustainable development in a globalized world", Journal of Management Studies, Vol. 50, No. 2, pp. 259-284.

Teng, C., Horng, J. and Hu, I. (2015), "Hotel environmental management decisions: The stakeholder perspective", International Journal of Hospitality and Tourism Administration, Vol. 16, No.1, pp. 79-98.

United Nations News (2015), “UN adopts new Global Goals, charting sustainable development for people and planet by 2030", available at: http://www.un.org/apps/news/story.asp?NewsID=51968\#.VwH2U84mXCO (accessed 31 May 2018).

United Nations (2017), The Sustainable Development Goals Report. United Nations Department of Economic and Social Affairs.

WCED (World Commission on Environment and Development) (1987), Our common future, Oxford University Press, Oxford (1987).

WEF, World Economic Forum (2009), "Energy Poverty Action, a joint initiative of the World Business Council for Sustainable Development (WBCSD)" available at: www.weforum.org/ (accessed 31 May 2018).

Waddock, S. (2008), "Building a new institutional infrastructure for corporate responsibility", Academy of Management Perspectives, Vol. 22, No. 3, pp. 87-108.

Wagner M., Alves, H. and Raposo, M. (2012), “A model for stakeholder classification and stakeholder relationships", Management Decision, Vol. 50, No. 10, pp. 1861-1879. 
Waligo, V. M., Clarke, J. and Hawkins, R. (2013), “Implementing sustainable tourism: A multi-stakeholder involvement management framework", Tourism Management, Vol. 36, pp. 342-353.

World Travel and Tourism Council (2018), “Agenda”, available at: https://www.wttc.org/agenda/ (accessed 31 May 2018).

Worley, W. (2017), "Famine stricken North Korea offers tourists the chance to plant rice on 'interesting labour tours"', Independent, Wednesday 13 September 2017, available at: https://www.independent.co.uk/news/world/asia/north-korea-tourism-plant-riceinteresting-labour-tours-famine-kim-jong-un-a7943876.html (accessed 31 May 2018). 
TABLES AND FIGURES

Table 1. Comparison between MDGs and SDGs

\begin{tabular}{|c|c|}
\hline \multicolumn{2}{|c|}{ Global goals set by the United Nations } \\
\hline $\begin{array}{l}\text { Millennium Development Goals } \\
\text { (MDGs) }\end{array}$ & $\begin{array}{l}\text { Sustainable Development Goals } \\
\text { (SDGs) }\end{array}$ \\
\hline $\begin{array}{l}\text { 1. End extreme poverty and } \\
\text { hunger } \\
\text { 2. Achieve universal education } \\
\text { 3. Promote gender equality } \\
\text { 4. Reduce child mortality } \\
\text { 5. Guarantee maternal health } \\
\text { 6. Combat diseases } \\
\text { 7. Ensure environmental } \\
\text { 8. Foster global partnership }\end{array}$ & $\begin{array}{l}\text { 1. End poverty in all its forms everywhere } \\
\text { 2. End hunger, achieve food security and } \\
\text { improved nutrition and promote sustainable } \\
\text { agriculture } \\
\text { 3. Ensure healthy lives and promote well-being } \\
\text { 4. Ensure inclusive and equitable quality } \\
\text { education and promote lifelong learning } \\
\text { opportunities } \\
\text { 5. Achieve gender equality and empower all } \\
\text { women and girls } \\
\text { 6. Ensure availability and sustainable } \\
\text { management of water and sanitation } \\
\text { 7. Ensure access to affordable, reliable, } \\
\text { sustainable and modern energy } \\
\text { 8. Promote sustained, inclusive and sustainable } \\
\text { economic growth, full and productive } \\
\text { employment and decent work } \\
\text { 9. Build resilient infrastructure, promote } \\
\text { inclusive and sustainable industrialization and } \\
\text { foster innovation } \\
\text { 10. Reduce income inequality within and among } \\
\text { countries } \\
\text { 11. Make cities and human settlements inclusive, } \\
\text { safe, resilient and sustainable } \\
\text { 12. Ensure sustainable consumption and } \\
\text { production patterns } \\
\text { 13. Combat climate change and its impacts by } \\
\text { regulating emissions and promoting } \\
\text { developments in renewable energy } \\
\text { 14. Conserve and sustainably use the oceans, seas } \\
\text { and marine resources } \\
\text { 15. Protect, restore and promote sustainable use of } \\
\text { terrestrial ecosystems and forests, combat } \\
\text { desertification, and halt and reverse land } \\
\text { degradation and halt biodiversity loss } \\
\text { 16. Promote peaceful and inclusive societies, } \\
\text { provide access to justice, and build } \\
\text { accountable and inclusive institutions } \\
\text { 17. Strengthen the means of implementation and } \\
\text { revitalize the global partnership for sustainable } \\
\text { development }\end{array}$ \\
\hline
\end{tabular}




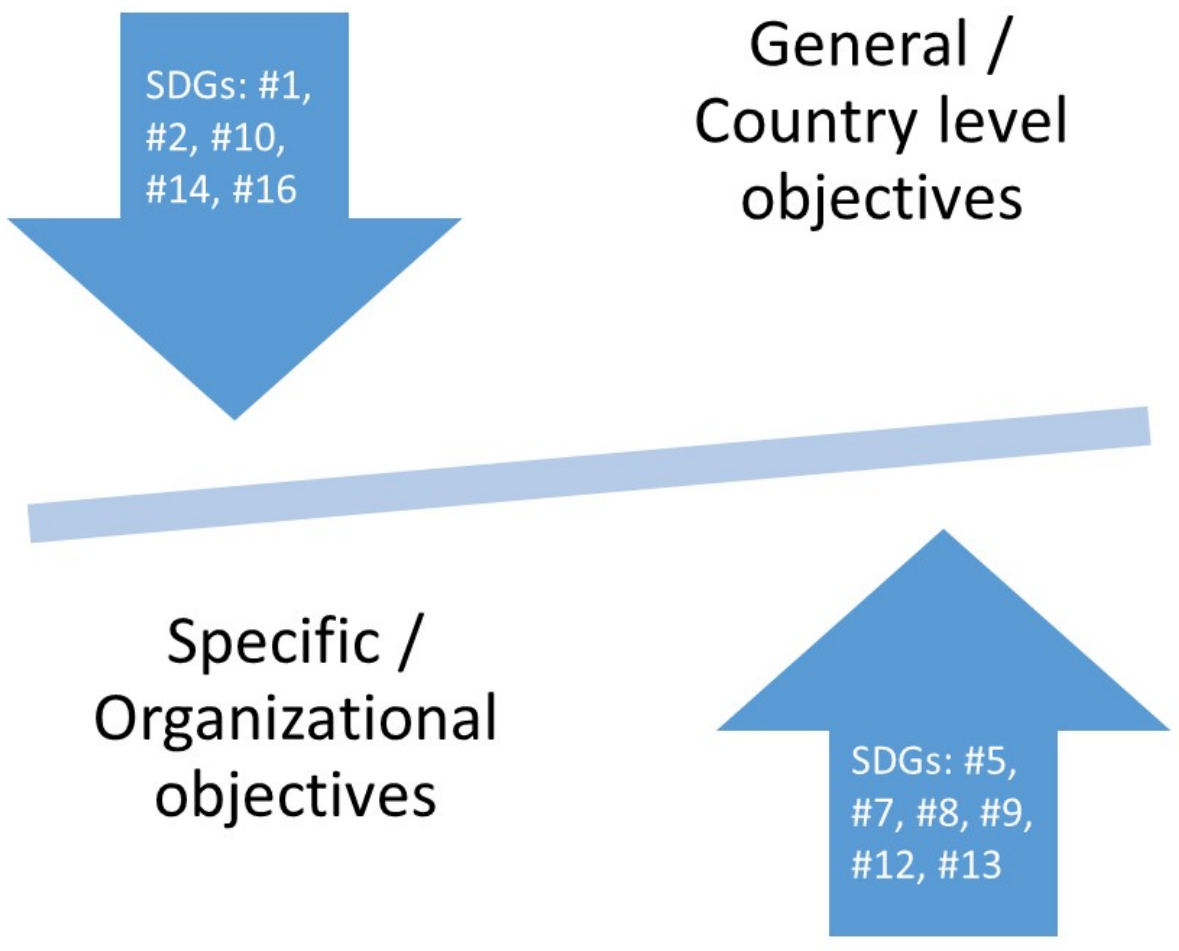

Figure 1. Examples SDGs according their general objectives and organizational objectives 


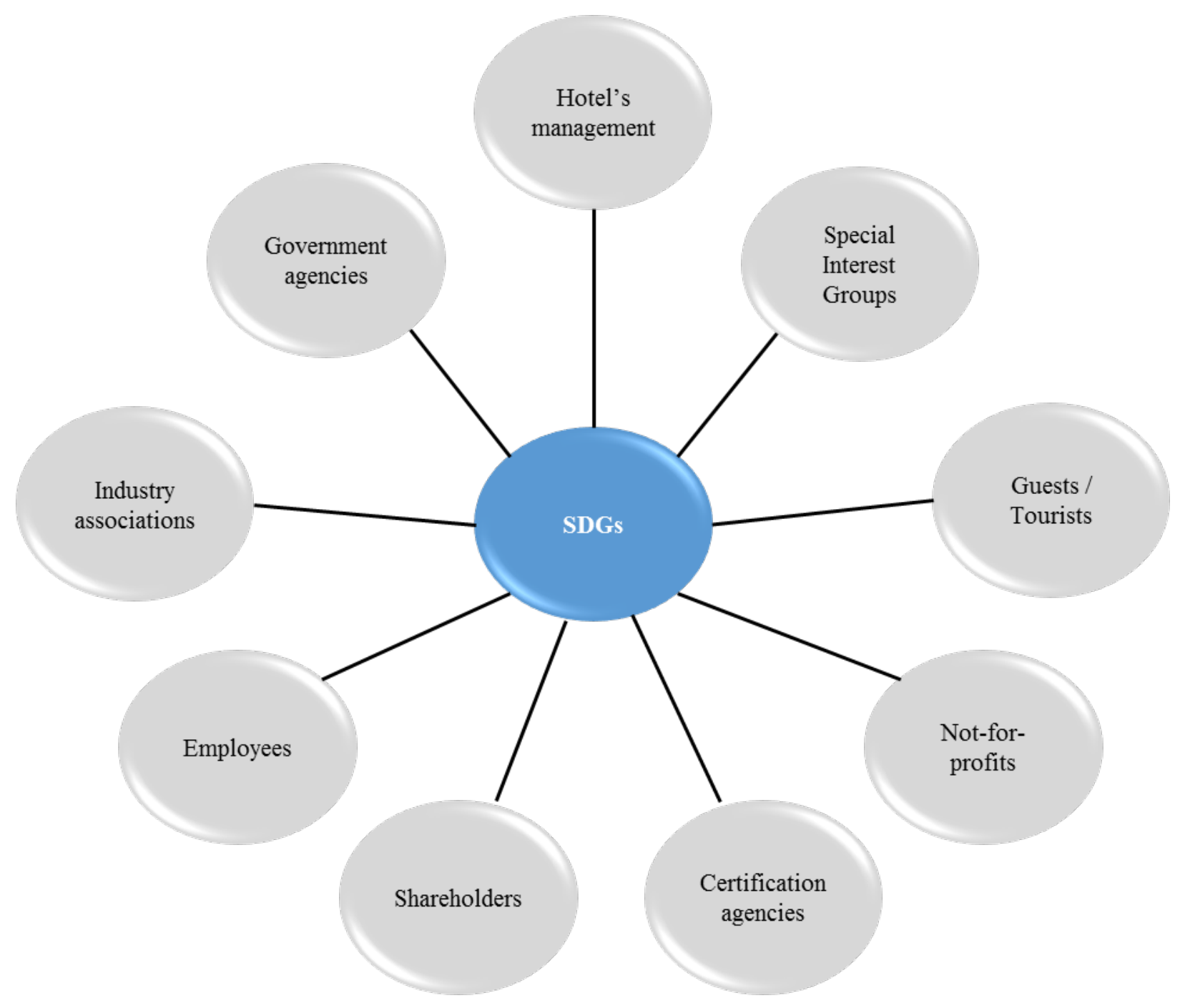

Figure 2. A multi-stakeholder perspective on SDSs 


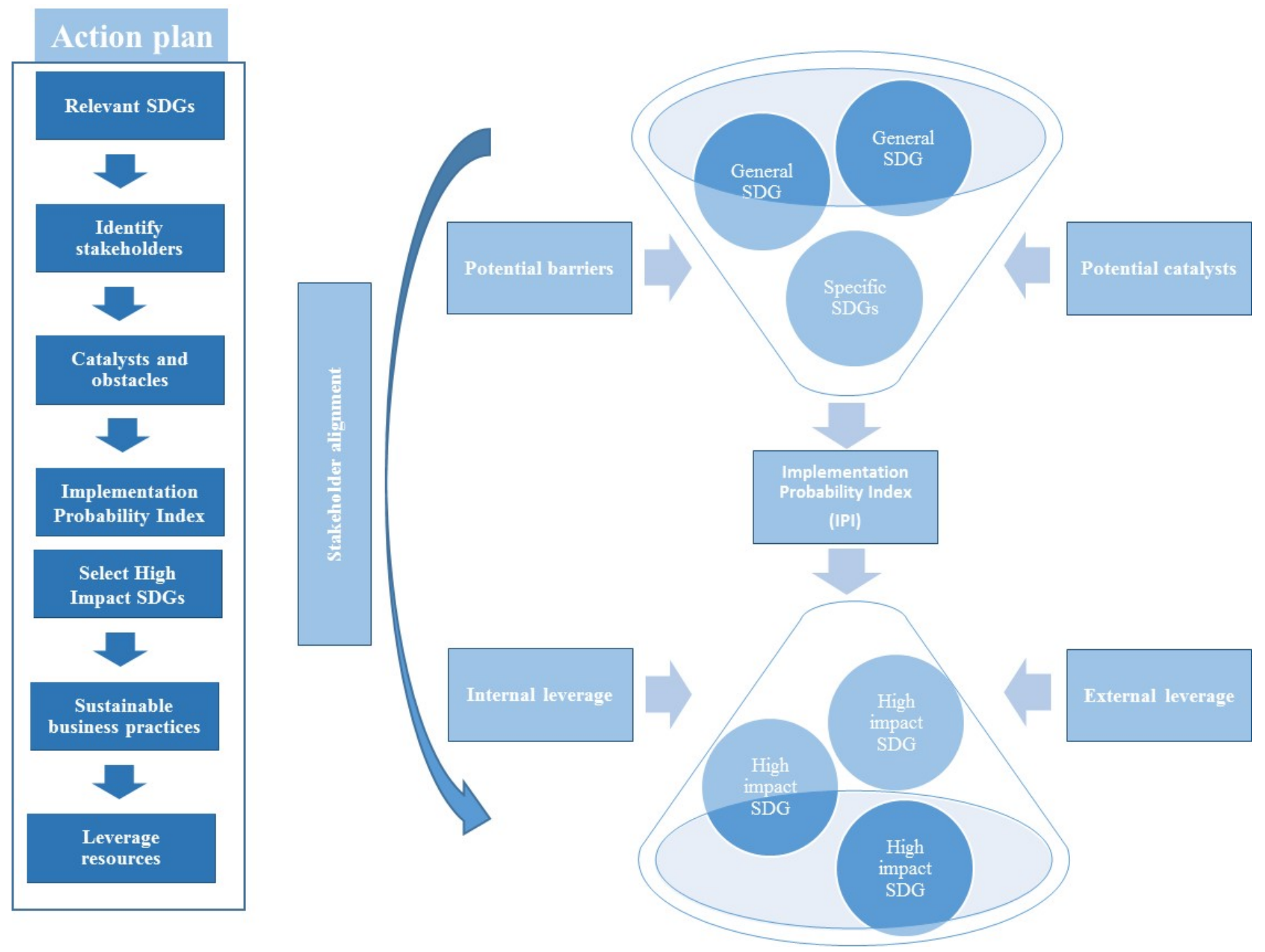

Figure 3. SDGs challenges: A stakeholder-filter-model 